translations revised, and supplied with an historical and explanatory appendix. Cambridge University Press, London, and University of California Press, Berkeley, California, Pp. 156-160 et passim.

\title{
Collision and Stranding at Sea
}

\section{Deacon}

Having studied marine statistics for a number of years, especially those concerning casualties at sea and in particular collisions between ships, the opening paragraph of the Traffic Separation Working Group's report (this Journal, 19, 4) is, to say the least, lacking confirmatory evidence on two counts.

I refer to the general statements which allege that:

(i) 'The main risk at sea today arises not as it used to from stranding and shipwreck, but from collision'.

(ii) 'In the open sea, where nearly $3 \circ$ per cent of all collisions occur . . .'

As both include the words 'at sea' or 'open sea' it is not unreasonable to suppose that they imply freedom to manœuvre under own power unhampered by depth of water or similar navigational restriction.

This being so, and not an irrational definition of the area of concern to the Working Party, what are the facts and how exactly do casualties at sea compare with those in other areas of marine interest throughout the world.

To find the right answer to the global problem is not easy and there are no short cuts, such as for example making a sample analysis in a limited area where traffic density is high, in order to arrive at fairly large numbers which are then used to deduce the statistical probability applicable to all areas.

Not only is this misleading but it denigrates the value of any study it is meant to support, primarily because it is restrictive in two dimensions; size of sample and location.

Many authorities produce statistics of one kind or another though, as they are all tailored to meet a particular need, no two can in fact be directly compared one with the other without some re-arrangement.

In short, there is at present no universality applied to the compilation of statistics relating to marine casualties and, unless there is loss of life or injury to persons, there is also doubt in some quarters that all casualties do in fact come to the notice of responsible authorities.

The most satisfactory solution therefore seems to be to mean the available information. This overcomes any tendency towards bias or personal inhibitions in the choice of facts presented in the individual tables.

As an example the following table has been prepared. 
Marine Casualties: WORLd STATISTICS

1 Collisions

(a) At sea.

(b) Pilotage waters.

(c) Rivers, canals, estuaries.
2 Strandings, including shipwreck, versus collisions in 1 (a) above

\begin{tabular}{|c|c|c|c|}
\hline $\begin{array}{c}\text { I } \\
\text { I. of N. W.G. } \\
\text { Vol. }(19,4) \\
\text { Appdx. } \\
\text { Table II }\end{array}$ & $\begin{array}{l}{ }^{2} \\
\text { U.S.C.G. } \\
\text { Nov. '65 } \\
\text { proceedings }\end{array}$ & $\begin{array}{c}3 \\
\text { Fricker } \\
\text { Journal, } 18 \\
163 \\
(\text { note } 1 \text { ) }\end{array}$ & $\begin{array}{c}4 \\
\text { Average } \\
\text { cols. } \\
1,2,3\end{array}$ \\
\hline $\begin{array}{c}\% \\
30 \\
12 \\
58 \\
\\
\text { Lloyd's } \\
\text { Register } \\
\text { I } 965.8: 1\end{array}$ & $\begin{array}{r}\% \\
8 \\
36 \\
56\end{array}$ & $\begin{array}{r}\% \\
6 \\
28 \\
66\end{array}$ & $\begin{array}{l}\% \\
15 \\
25 \\
60\end{array}$ \\
\hline
\end{tabular}

1. The article states that the figures were derived from Liverpool Underwriters Association monthly statistics.

2. Figures from L.U.A. monthly statistics, but not reproduced by $\mathrm{Mr}$. Fricker.

It is unfortunate that none of these statistics reflect a trend, but $\mathrm{Mr}$. Fricker states that collisions in the open sea, even in reduced visibility, occur far less frequently. This is supported in the article, The Statistics of Collisions at SeaII (this Journal, 19, 2).

It is also to be noted that as regards the most important causes of total loss at sea, Lloyd's Register report that, for every ship over 400 tons lost by collision throughout the world between 1960 and 1964 , ten were lost by stranding or running aground. The 1965 figures were about one collision to eight strandings.

To conclude, it is abundantly clear that the major risk at sea today continues to be stranding including shipwreck, while the number of collisions in the open sea are relatively few compared to the overall total. Collisions at sea are certainly a lot less than is suggested by the Report.

On the evidence available, the Traffic Separation Working Group may wish to reconsider the statements in the opening paragraph of its latest Report and align itself more correctly with the true facts of the situation, which are, after all, the basis on which its whole programme of work is founded.

\section{Mr. W. Richey (who compiled the Working Group's Report) writes:}

The analysis by F. W. Fricker (U.S. Naval Oceanographic Office) published in the Journal $(18,163)$ shows quite clearly on the basis of quoted statistics that collision 'now ranks as the leading maritime casualty' (to quote his paper). Admittedly, a comparison of statistics is not always as straightforward as it may 
look. However, Fricker's Fig. I, showing the annual increase in collisions and decrease in groundings over the period 1954-63 clearly establishes what the Report claims, that the main risk at sea today arises from collision. To compare figures of total losses or partial losses, as opposed to the total number of accidents, as Mr. Deacon does, is to obscure the issue so far as risk is concerned. The outcome of the accident (in terms, for example, of damage or loss of life or value) is to a large extent fortuitous. Imperfect though they may be, the overall figures are all we have to go by and these clearly substantiate the Report's claim.

Unless Mr. Deacon disputes the statistics quoted in the Report, it is meaningless to say that 'Collisions at sea are certainly a lot less than is suggested by the Report'. The only suggestions are based on the figures quoted.

Mr. J. H. Beattie (who was responsible for the analysis of collision statistics given in the Report) writes:

There are several authorities which endeavour to list all marine casualties reported and all of these show that the number of collisions now far exceeds strandings. In this Report, reference is made to one official source, which is the U.S. Coast Guard annual report on U.S. marine casualties. This is an extremely detailed report and it shows in the fiscal year 1965 there were a total of 3095 marine casualties reported to them. 633 (20 per cent of all) casualties were groundings, whereas 1682 ( 55 per cent) were collisions. However, $43^{8}$ of these collisions were with fixed objects. Another official reference might have been chosen, that of the U.K. Board of Trade annual report on U.K. registered shipping casualties. The 1963 report lists 1619 casualties in vessels over 100 gross registered tons. These included the following collisions and strandings:

\begin{tabular}{lcc} 
Total loss & Collisions & Strandings \\
Serious casualties & 6 & 2 \\
Minor casualties & 2 & 0 \\
\hline All casualties & 379 & 169 \\
\hline
\end{tabular}

These figures are typical of recent U.K. experience where there are now twice as many collisions as strandings. Forty years ago, U.K. strandings are believed to have far outnumbered collisions. Since 1946 there has been little change in the level of total U.K. collision casualties, but the rate of U.K. strandings was halved between 1949 and 1955, probably as the result of the widescale fitting of electronic navigation aids. A report from an underwriters' association also again shows there are more collisions than strandings. The Liverpool Underwriters Association casualty return on all casualties over 500 gross registered tons reported in 1963 shows:

\begin{tabular}{lcc} 
& Collisions & Strandings \\
Total losses & 21 & 71 \\
Partial losses & I 793 & 978 \\
\hline Total casualties & 1814 & 1049 \\
\hline
\end{tabular}


Mr. Deacon's second point is that the statement 'in the open sea, where nearly 3o per cent of all collisions occur' is misleading and unsatisfactory for local use anywhere in the world-if this is required. He apparently accepts this figure for European waters with which the Working Group was principally concerned and which apparently covers more than half the world's collisions. However, he deduces from the 1965 U.S.C.G. annual report that collisions at sea under U.S.C.G. jurisdiction are a lower proportion than 30 per cent-he gives a figure of 8 per cent. However, it must be appreciated that these summaries include many inland water collisions in a totally different traffic system such as on the U.S. western rivers (Mississippi-Missouri River System). Collisions in European river systems were also ignored in the Report for these reasons. It should be observed also that U.S. casualties only reflect a relatively small proportion of all casualties; U.S. conditions are very different to European, and routing is already in force in large areas like the Great Lakes. The figures in Appendix I to the Report indicate that collisions in the open sea in North American waters form a lower percentage than elsewhere. Perhaps the best guide to valid U.S. experience is contained in the comprehensive study made in 1960 by the U.S.C.G.of 199 collisions which took place in 1957,1958 and 1959. This gave 13 per cent in what was described as 'open sea', 28 per cent in congested waters and 59 per cent in narrow channels. There seems little point in taking Fricker's figures, which are based on a small sample, and averaging these with others, because they are identical to those quoted by the writer in 1962 and are taken into account in the comprehensive figures included in Appendix 1 to the Report.

The Working Groups on Traffic Separation at Sea were not principally concerned with producing precise collision indexes for the world or special areas even if these have any real relevance. They were concerned with providing a solution to the existing collision problem in converging areas. They were aware that these collisions in the 'open sea' form a relatively small proportion of all collisions but that experience shows that these collisions are generally of a much more serious nature than those in terminal areas. It is believed the Working Groups were also concerned with establishing a traffic pattern in converging areas for the future of world seaborne trade. Clearly they had in mind the operation of very large and fast ships in the future with an increasing number of ships at sea. So far they have only concerned themselves with trying to deal with problems in the 'open sea' as opposed to the 'terminal or port areas'. 